\title{
Task Division amongst the Iban Farming Community within Men and Women in Kuala Tatau, Sarawak, Malaysia
}

\author{
Daniel Ugeh U.1 \\ Salfarina Abdul Gapor² \\ Novel Lyndon ${ }^{3}$ \\ Mohd. Nor Shahizan Ali ${ }^{4}$ \\ Sivapalan S. Selvadurai ${ }^{5}$

\begin{abstract}
${ }^{1}$ Research Officer, School of Social Sciences, Universiti Sains Malaysia; dnielusm@yahoo.com.my ${ }^{2}$ Associate Professor, School of Built Environment, University College of Technology Sarawak, Malaysia; salfarina@ucts.edu.my ${ }^{3}$ Associate Professor, Faculty of Social Sciences and Humanities, Universiti Kebangsaan Malaysia; novel@ukm.edu.my ${ }_{4}$ Senior Lecturer, Faculty of Social Sciences and Humanities, Universiti Kebangsaan Malaysia; shahizan@ukm.edu.my

${ }^{5}$ Associate Professor, Faculty of Social Sciences and Humanities, Universiti Kebangsaan Malaysia; sivap02@gmail.my
\end{abstract}

\section{Doi:10.5901/mjss.2015.v6n4s3p136}

Abstract

Gender issues have always been the centre of attention when it comes to the study of farming activities in rural areas. This article aims to study the task division amongst the Iban men and women farmers in the dry rice paddy fields by the coast of Kuala Tatau, Sarawak. The method chosen in the course of this study was the qualitative research method by interviewing and discussing amongst focus groups and also observing the farmers in Sungai Semanok and Kuala Serupai. The outcome of this study was that most women worked full time in the paddy fields, whereas men work part time as contract workers to support the family's household expenses. The men would only help the women when performing physical demanding tasks such as spraying pesticides in large quantity, transporting large amount of paddy, performing the manggul'ritual and paddy harvesting. For married farmers who works full time in the paddy fields, the men would seek for extra income by fishing or working as a contract worker as soon as they have completed work in the paddy fields, especially during waiting period for the burning, seedling and paddy harvesting and also when the harvest seasons end. This task division also was practice at home, especially for threshing and cleaning of the paddy from its dregs and processing it into rice. In conclusion, the task division amongst gender has always been divided according to the difficulty of the task, distance and private-public domains.

Keywords: Gender and development, rural development, sustainable agriculture, Iban farmers

\section{Introduction}

Since early 1970's the Iban community has been regarded as the largest farming community in the state of Sarawak especially in the rural areas (Hew Cheng Sim, 1985; Ngidang \& Abdul, 1999; Jayum, 1994). There are two types of paddy planted by the Iban farmer's namely dry paddy and hill paddy (Hew Cheng Sim, 1985). Hill paddy is planted at the mountain slopes in the highlands of Sarawak, such as Kapit, Ulu Mukah, Kanowit and Song. However dry paddy is planted by the farmers in the lowland region typically by the coast of Sarawak such as Bintulu, Balingian, Mukah, Kuching and Miri. In the beginning, farming activities are mainly done to fulfil the needs of the farmer's household, but whenever there is a need to gain extra income namely to support their family expenses in sending their children to school, or there are any leftovers, the farmers would sell off the extra rice (Lyndon et al. 2011; Ngidang \& Abdul, 1999). Self-sustaining paddy farming has been a practice amongst the Iban farmers which only includes close family members. Typically, farming activities has been done in a constant shifting manner from one area to the next within the farmer's own land. This method of farming has been practiced by most of the ethnic groups consisting of more than 76.5 percent of the total region in Sarawak (Ngidang \& Abdul, 1999). This was more frequently practice as compared to the rotating crops method of farming which involves the planting of different crops and then the clearing of undergrowth by burning them. This

${ }^{1}$ Animistic rituals performed by farmers who still believe in animism before cleaning the forest. 
farming method involves mostly on 'man power' such as the farmers ploughing and also harvesting. Amongst the most common tools used were the seedling tool and the hoe. In terms of time-span, the shifting method of farming is used more frequently in a short time-span and the crop rotating method is used where the lands were left to be "rang" (Pelzer, 1945). According to Lyndon et al. (2011) and Hew Cheng Sim (1985) traditional practices in farming are still widely practiced amongst the Iban farmers especially in planting dry paddy. There are many believes, customs, taboos and spirits that exists in farming according to the Iban community in Sarawak (Hew Cheng Sim, 1985).

\section{Paddy Ritual amongst the Iban Community}

Many myths and legends often circulate amongst the aboriginal community in Sarawak that is closely related to the paddy planting and rituals in adoration of the paddy. "Pulang Gana" is one of the most frequently cited spirits in these myths. So as the relationship with the positioning of the seven stars in the sky along with important dates or day this is suitable for paddy planting (Mohd Taib, 1988). Meanwhile, previous studies by Muhammad Harun (2007) clearly illustrated that the Iban community performed dance rituals in adoration of the paddy spirits. The Tolak Bala Dance or most commonly known as The Sigar Dance was performed when the harvesting season ended as a sign of gratitude towards the penunggu [spirit] which has blessed the farmers marking a bountiful paddy harvest. In this ritual, offerings such as fruits, cooked rice in woven coconut leaves and eggs is prepared for the penunggu. These offering are placed in a bamboo woven basket knows as a taya. Before the dance ritual, the farmers will prepare candles, coconut oil and turmeric rice for the penunggu. As soon as the dance ends, the offerings will be presented to the penunggu. Apart from that, there are also taboos within the Iban community regarding the excess of food made from rice as it may jeopardize the spirit of the paddy (Hew Cheng Sim, 1985). Male farmers are also prohibited to eat when walking to the paddy fields as it may cause poor harvest.

In the wider literature, most studies on sex differences and task divisions as consequence of roles imposed on men and women relates to other kinds of differentiation in rural communities such a private-public and inside-outside (Stratigaki, 1988; Chambers, 1994; Chamhuri, 1985). Most of these studies view farmers and peasants as a unitary group in rural communities in so far as it relates to agricultural produce (Chambers, 1994; Lyndon et al. 2011; Jamilah, 1992). The need for studies to examine the relations between family members and forms of gender division of labour or task division (Stratigaki, 1988; Jamilah, 1992) are more pronounced in rural faming, especially paddy farming which is under studied.

\section{Methodology}

Kuala Serupai and Sungai Semanok were chosen as the location of study to enable the study of task division and allocation amongst gender in the paddy farming community to be conducted. In this study, a total of 17 farmers were interviewed, eight of which were farmers from Kuala Serupai and the remaining nine were farmers from Sungai Semanok. To attain further information, researchers were involved in identifying farmers with varying characteristics such as age range, gender and experiences while they were involved in the paddy farming. Therefore, a qualitative method utilizing varying techniques such interviews, focus groups discussion and also observation were undertaken. The interview was conducted by meeting farmers from house to house. During the interview, researchers also seek for approval from the farmers to take photographs of the farming tools and paddy harvesting practices there were in their houses. Besides that, guided questionnaire were used to identify farmer's profile which included information such as gender, income, marital status, age and other important details. Next, researchers also followed the farmers to the paddy fields to observe the performance of ritual or miring which is usually performed by one of the farmers in Sungai Semanok. In the focus groups discussions which were conducted in both villages, a group of five to seven farmers were involved in each session. The data collected was then analysed by using the content analytical method by recording the verbal responses given by these farmers and later transcribing them into textual data to facilitate to the coding of themes which was chosen and the frequency of words being repeatedly used amongst the farmers.

\section{Research Finding}

\subsection{Farmers Profile}

This study involved 17 farmers who were interviewed in both villages namely eight from Kuala Serupai and nine from Sungai Semanok. In terms of age, the average age of farmers whom participated in the interview was 58 years old as 
illustrated in Table 1.Apart from the data obtained which shows the marital status amongst the farmers, one was still a bachelor; two were widowed whereas the rest were married. In terms of income, the average income of farmers in both villages was only 371 Malaysian Ringgit, a figure well below the poverty line.

Table 1: Respondent's Profile in Kuala Serupai and Sungai Semanok

\begin{tabular}{|c|c|c|c|c|c|}
\hline Farmers & Gender & Number of Household & Status & Job & Average Income (MYR) \\
\hline Farmers A(KS) & Male & 2 & Married & Farmer & 300 \\
\hline Farmers B (KS) & Male & 2 & Married & Farmer & 200 \\
\hline Farmers C (KS) & Male & 2 & Married & Farmer & 100 \\
\hline Farmers D (KS) & Female & 2 & Married & Farmer & 800 \\
\hline Farmers E (KS) & Male & 2 & Married & Farmer & 200 \\
\hline Farmers F (KS) & Male & 2 & Single & Farmer & 600 \\
\hline Farmers G (KS) & Female & 2 & Divorced & Farmer & 300 \\
\hline Farmers H (KS) & Female & 2 & Married & Farmer & 200 \\
\hline Farmers I (SS) & Male & 6 & Married & Farmer & 300 \\
\hline Farmers J (SS) & Male & 4 & Married & Farmer & 300 \\
\hline Farmers K (SS) & Male & 10 & Married & Farmer & 500 \\
\hline Farmers L (SS) & Female & 5 & Married & Farmer & 600 \\
\hline Farmers M (SS) & Female & 2 & Married & Farmer & 200 \\
\hline Farmers N (SS) & Female & 5 & Divorced & Farmer & 200 \\
\hline Farmers O (SS) & Female & 4 & Married & Farmer & 500 \\
\hline Farmers P (SS) & Female & 7 & Married & Farmer & 300 \\
\hline Farmers Q (SS) & Female & 5 & Married & Farmer & 800 \\
\hline
\end{tabular}

Note: $\mathrm{KS}^{\star}$ represents Kuala Serupai whereas SS* represents Sungai Semanok

\subsection{Task division amongst the farmers according to their genders}

The finding of this study shows that there is a clear task division amongst the male and female farmers in the Iban community in Sungai Semanok and Kuala Serupai. Study shows that there is no difference in terms of job scope amongst male and female farmers in both villages. Researchers had divided the data according to two categories namely the female farmers who work full-time in the paddy fields whereas their husbands help out once in a while; and both male and female farmers working fulltime in the paddy fields. Table 2 shows four scenarios of task division amongst the male and female farmers in Sungai Semanok and Kuala Serupai.

Table 2: Task division according to different scenarios

\begin{tabular}{|l|l|}
\hline Situation 1 & The wife works at the paddy fields, whereas the husband seeks extra income \\
\hline Situation 2 & Both husband and wife works together at the paddy fields \\
\hline Situation 3 & Task division in processing paddy from home \\
\hline Situation 4 & Task division during miring \\
\hline
\end{tabular}

\subsection{The wife works at the paddy fields, whereas the husband seeks extra income}

For the first category, the female farmers work in the field independently as their husbands works as contract workers to support the household expenses and pay the fees for their children's education. However, the husband would help their wives perform physically demanding tasks such as spraying pesticide, cutting down the paddy, manggul [cleaning] and miring [prayer to ancestor for paddy safety] during the paddy harvesting process and also transporting the paddy from the fields to their homes. According to Misah, a 34 year old female farmer from Kuala Serupai, her husband works as a security guard in an oil palm estate which is nearby and he will help her during his days off and he will do all the physically demanding task such as spraying pesticide, seeding, miring, manggul and also transporting the paddy. Besides that, her husband also helps her in selecting the seed for the paddy according to their personal preference. Besides working in the paddy field, Misah is also responsible in most household obligations such as sending their children to school. Apart from that, most women who work along with their husbands in the city of Bintulu as factory works are also involve in paddy planting. This alternative pathway was chosen as the women had to work and manage their 
children who had to study in the city. Therefore, she only returns to the long house in Sungai Semanok during the weekend and rarely receives support from her husband. As a working mother herself, she has to manage most of the household obligations, and as consequence she could only manage paddy planting in a small scale only to satisfy her household needs.

\subsection{Both husband and wife works together at the paddy fields}

In the dry paddy fields, task division begins from the manggul practice. For the farmers who still practices this ritual, the men will do most of the work whereas the women help prepare items needed for the manggul such as piring which is usually prepared from home. For the farmers who still practices manggul and Christianity in Serupai, most of the women will lead the prayer processions as they are more experienced compared to the men in performing the manggul. When it comes to clearing of the land, the men will be in charge of clearing weeds, spraying pesticides and sometimes clearing tree. Whereas for the women, their role only take care of clearing the growth of grass in the paddy land. When it comes to clearing the land by burning, both men and women will do their share of tasks together. In paddy planting and bertambak [create limits], the men will be responsible in digging holes in the soil then the seedlings are inserted into the hole and the replanting of the paddy is completed. The men will transport the seeds and stems of the paddy which had been plucked out and bring them to a replanting location. As for the women, they are responsible in picking out the healthy paddy stems for replanting and also replanting the stems into the holes which had already been dug by the men. In the harvesting season, both men and women will work together and harvest the paddy, as men would be responsible of transporting sacks of harvested paddy. The women will ensure that the storage of the harvested paddy was done properly and that no stems are left on the ground. Apart from that, whenever the paddy is wet, the women will dry them first.

\subsection{Task division in processing paddy from home}

In Kuala Serupai and Sungai Semanok, task division among men and women does not only happen at the paddy fields but also at home during paddy processing. This process involves splitting the paddy seeds from the stem then processing the paddy into rice, afterwards the paddy and the rice will then be stored. As for farmers who still practice the ngindik ritual, a lantai panggau (places for ritual), is prepared by the men before the ritual begins. When performing the ritual, the men separates the paddy seeds from its stem or ngindik, whereas the women makes sure that the paddy seeds had throughout fell out from the stems. The women are also responsible of separating the seed from the stem of the paddy by using the mortar, next the seeds will be stored into sacks and finally be kept before the paddies are taken out for the nyembi (drying) process which is the final process before the husk less paddy become rice.

\subsection{Task division during miring}

Task division amongst the men and women does not only include economical and agricultural aspects but also in rituals practices especially for the farmers who are still practicing animism. Whilst the ritual practices were being performed, the researchers were also involved in participating in one of the miring done by the farmers in Sungai Semanok. In the miring ritual, as for the ngibun burung (asking for help from ancestor), researchers found out that the women were responsible for preparing different items for the ritual, namely tobaccos, palm wrapped cigarettes, boiled eggs, chalk, betel vine, betel nut and rice wine. These items were prepared a day before the miring ritual in the dry paddy fields. On the same day, the men would invite their friends and fellow farmers within the same long house to participate in the miring ritual at the dry paddy fields on the following day. The men would also be responsible for preparing the pigs and chickens that will be slaughtered as a symbolic for the miring which then be served to the guests. On the day of the miring, the women will attend earlier to assist the wife of the farmer who will be doing the miring by helping out in preparation of cakes and coffee as breakfast before the ritual begins. At the meantime, the men will look for firewood and start the fire for the purpose of cleaning the fur and feathers of the chicken and pig before slaughtering. When the miring ritual begins, the men will be responsible in the ritual performing whereas the women will assist them in preparing and dividing the items needed during the ritual. When the miring is done, the men will slaughter the chicken and pig, however they also will cut the meat into pieces before handing to the women for cooking. There are also some of the men who will go out in search of the palm cabbage from the coconut and sago plant for them to be cooked with the meat. The task division during the miring ritual will end with cleaning up of plates and utensils used during the feast. The illustrations in figure 1 and 2 were taken by the researchers while attending the miring ritual for nginbun burung along with a group of Iban farmers in Sungai 
Semanok on the $26^{\text {th }}$ of July 2012.

\section{Conclusion}

The findings show that the task division amongst the male and female farmers within the Iban community in Kuala Tatau is still being practiced. Even though Sungai Semanok is near to the city of Bintulu and has networks of roads leading into the city, however this does not make any difference in gender relationships especially when it comes to task allocation amongst the farmers. Finding shows that task division amongst the Iban farmers in Kuala Tatau does not only include farming activities in the paddy fields but also the paddy processing done at home and its general responsibility towards the social economical aspect in its household. In terms of social economic, the male farmers are responsible to seek for extra income to support the household expenses. Task division amongst the men and women in the Iban community shows that the role of husbands in the family plays an important part to generate income for the whole family. However the women do not only play the role as wives but also doubled as both mothers and fathers for their children whenever their husbands go to work somewhere else. The women does not only make sure that their children does to school, received sufficient food but also makes sure that the paddies in the fields are in good conditions to enable a quality yield of paddy harvest. In conclusion, the task division amongst male and female farmers plays an important role to ensure that the basic needs of a family would be well preserved.

\section{Acknowledgment}

The researcher would like to thank Climate Change chair UKM- Yayasan Sime Darby (Project Code: ZF-2013-013) which enables smooth implementations of this research.

\section{References}

Chambers, R. (1994). The origins and practice of participatory rural appraisal. World Development, vol.22 (7): 953-969.

Chamhuri, S. (1985). Persistent poverty among paddy farmers: impact and implication of the Paddy Subsidy Scheme. Paper presented at Seminar on Problems and Prospects on rural Malaysia, Consumer Association of Penang, Penang, November.

Hew Cheng Sim. (1985). The Effect of a Land Resettlement Scheme on Rural Iban Women.

Kuala Lumpur, Malaysia: Asian and Pacific Development Centre Jamilah Arrifin. (1992). Women and Development in Malaysia. Pelanduk Publications, Petaling Jaya, Selangor Darul Ehsan

Jayum Jawan (1991). Political Change and Economic Development among the Ibans of Sarawak East Malaysia. Unpublished doctoral dissertation, University Of Hull.

Jayum Jawan. (1994). Iban Politics and Economic Development The Patterns and Change. Penerbit UKM, Bangi.

Lyndon, R. Moorthy , A. C. Er and S. Selvadurai. (2011). Native Understanding of Participation and Empowerment in Community Development. Journal of Social Sciences, 7 (4):643-648.

Muhamad Bin Harun. (2007). Adat dan Budaya Masyarakat Malaysia. Mutiara IImu Enterprise Mohd Taib.(1983). Kajian budaya dan Masyarakat di Malaysia. Dewan Bahasa dan Pustaka, Kuala Lumpur

Muhamad Bin Harun (2007).AdatdanBudayaMasyarakat Malaysia. Kuala Lumpur: Mutiara IImu Enterprise.

Ngidang, D. \& Abdul, R. A. (1999). Rural Cooperative Societies and Community Development in Sarawak, in Victor T. King (eds.), Rural Development and Social Science Research: Case Studies from Borneo, pp.251-267. Borneo Research Council.

Pelzer, Karl. (1945). Pioneer settlement in the Asiatic tropics; Studies in land utilization and agricultural colonization in Southeastern Asia, New York: American Geo-graphical Cociety

Stratigaki, M. (1988), Agricultural modernization and gender division of labour: The case of Heraklion, Greece. Sociologia Ruralis, 28: 248-262. doi: 10.1111/j.1467-9523.1988.tb00343.. 